\title{
Helseulikhetene består: hvordan kan de forklares og bekjempes?
}

Under Den annen verdenskrig ble det i Storbritannia lagt planer for et etterkrigssamfunn med større sosial rettferdighet $(1,2)$. Mellomkrigstidens klassekamp og sosiale motsetninger skulle avløses av samarbeid og fellesskap. Visjonene fra Beveridge-planen hadde sine paralleller i de nordiske landene, og fikk i Norge sitt langvarige politiske uttrykk i Gerhardsen-epoken og det sosialdemokratiske hegemoni til langt inn mot 1980-tallet. Enigheten i hovedlinjene i politikken var så stor at det antakelig er riktig å si at alle politiske partier i denne perioden var "sosialdemokratiske".

Troen på den sosiale rettferdighet og det nye klasseløse samfunn gjorde at man på mange områder slutte å snakke om sosiale forskjeller eller klasser (3). Alle skulle være like. Det meste av norsk statistikk innen helse- og sosiale forhold ble uttrykt som gjennomsnitt. Den epidemiologiske forskningen fulgte den offentlige statistikkens normer, og sluttet å benytte sosiale lagdelingsvariabler (3). En ny generasjon av amerikanskinspirerte sosiologer mente dessuten at klassebegrepet var foreldet. Sosioøkonomiske gradienter i helse og sykdomsrisiko ble et ikke-tema.

I Norge slo denne forestillingen om et mer likeverdig samfunn sprekker på 1990-tallet, da det kom dokumentasjon på at vi bak likhetsideologien dro med oss betydningsfulle sosiale ulikheter i helse (4). Hva verre var, sammenliknende studier konkluderte med at den relative ulikhet i Norge (og Sverige) var større enn i andre europeiske land (5-6). Da man fant større forskjeller i forventet levealder mellom bydelene i Oslo enn mellom forskjellige OECD-land, falt de siste rester av den sosialdemokratiske helseuskyld bort $(4,7)$.

I rettferdighetens navn skal det tilføyes at alle sosioøkonomiske grupper har fått del i den positive utviklingen i dødelighet de siste 30 årene, og at de absolutte ulikheter i forventet levealder ut fra sosial rang ikke er dramatiske. Utviklingen på 1990-tallet har vist at de rike er blitt rikere, men de fattige er ikke blitt fattigere (8). Dødeligheten sank på 1990 tallet med 22\% for menn og 11\% for kvinner i aldersgruppen 1-64 år og spedbarnsdødeligheten og den postneonatale dødeligheten er blitt halvert de siste 10 årene (8).

På den annen side kommer det frem et urovekkende bilde av betydelige sosiale forskjeller i selvopplevd helse og uførhet (9). Det er også blitt en ytterligere sosial polarisering når det gjelder røykevaner, noe som vil slå ut i betydelige sosiale helseforskjeller i framtiden. Den samme sosiale polariseringen kan vi se konturene av for de fleste andre livsstilssykdommene.
Den nye oppmerksomheten omkring sosial ulikhet $i$ helse har resultert $i$ et oppsving av forskningsaktivitet med bidrag fra flere disipliner: epidemiologi, sosialmedisin, samfunnsvitenskap og økonomi, for å nevne noen $(6,10,11)$. Nasjonale og internasjonale forskergrupper publiserer nå fortløpende deskriptive og analytiske studier på metodologisk høyt nivå. Noe av dette spennende materialet ble nylig presentert og diskutert på to internasjonale konferanser i Norge: Konferansen Making a difference - social inequalities in health, Gardermoen 14.-16. mai 2001, og 16. Nordic Conference in Social Medicine \& Public Health: Social inequality and inequity in health, Bergen 17.-19. august 2001.

Ideen om dette temanummeret av Norsk Epidemiologi sprang ut av de to konferansene, ut fra et ønske om å kunne presentere et bilde av norsk forskning på dette viktige og utfordrende området. Vårt ønske er at tema- og metodeartiklene i denne samlingen skal inspirere til bredere og dypere analyser av den sosiale ulikhetsdimensjonen, både i studier av spesifikke sykdommer eller pasientgrupper, slik Mette Brekke nylig har gjort med sin doktoravhandling (12), og i de store befolknings- og levekårsundersøkelsene (13).

Temanummeret åpner med Peter F. Hjorts åpningsforedrag fra Gardermoen-konferansen, der han på sitt sedvanlige enkle og klare vis laget en skisse over de store utfordringene som ulikhetene skaper. Hans anvisninger av hvor forskningsinnsatsen nå behøves mest er neppe kontroversielle: en bedre forståelse av årsaksmekanismer og forskning på tiltak.

Et viktig teoretisk og metodologisk spørsmål er knyttet til hvordan vi forstår og måler sosial ulikhet. I en oversiktsartikkel minner Annett Arntzen oss på at sosial klasse kan forstås ut fra flere ulike teoretiske ståsteder, hvorav konfliktteori og markedsteori representerer to fundamentalt forskjellige perspektiv. Tidligere samfunnsvitenskapelig forskning bygget gjerne på varianter av en marxistisk klasseforståelse, hvor det var et avgjørende skille mellom kapitalister og arbeidere og hvor man på forskjellig vis forsøkte å konstruere mellomliggende klasser ut fra deres forhold til produksjonsmidlene. Mot dette står den weberianske lagdelingsmodell, som ordner samfunnet i strata ut fra rikdom, makt og anseelse. I dagens empiristiske ulikhetsforskning er det denne modellen som har vunnet frem, men fortsatt gjenstår mange uoppklarte spørsmål knyttet til hvordan ulikhet best kan operasjonaliseres.

Krokstad, Ringdal og Westin belyser dette problemet i sin artikkel, hvor de med utgangspunkt i Nord- 
Trøndelagsundersøkelsens grove yrkesinndeling lager en sosial gradientskala tett opp til den internasjonalt anerkjente Erikson Goldthorpe Portocaro (EGP) skalaen. Formelt skal EGP-skalaen genereres direkte fra de enkelte yrkeskoder. Etter oppkopling til folkeregisterdata viser sammenlikningen mellom de to metodene at selv en forholdsvis grov yrkesgruppering lot seg rimelig godt reklassifisere til en EGP-skala, men at detaljerte yrkesopplysninger er nødvendige for en optimal rang-klassifisering. Denne analysen vil danne en nyttig bakgrunn for arbeidet med de store befolkningsundersøkelsene i Norge.

De senere år har det kommet frem nye synspunkter som kan bidra til å forklare hvorfor de sosiale helseulikheter produseres og reproduseres. Fra en forholdsvis enkel eksposisjonsmodell, hvor man har forsøkt å avveie strukturelle og miljømessige helsebelastninger mot individuelle/atferdsmessige risikofaktorer, har utviklingen beveget seg mot mer komplekse forklaringsmodeller som åpner opp for resiproke påvirkninger gjennom livsløpet. Sosiale ulikheter i helse sees her som produktet av en lang rekke fordelaktige eller ufordelaktige omstendigheter fra fosterliv til voksen alder. Dette omfatter biologiske, ernæringsmessige, miljømessige, sosiale, kulturelle og psykologiske faktorer, som i sum bremser opp eller fremmer det helsepotensial individet er genetisk tildelt. Noess og Claussen gir en oversikt over "livsløps-modellen" som de ser som en sammensmeltning mellom den multifaktorielle årsaksmodellen og programmeringshypotesen særlig lansert av Forsdahl og Barker (15).

Eriksen og Ursin tar derimot utgangspunkt i kognitiv stressteori og fremmer en læringsteoretisk modell for hvordan helseulikheter utvikles. Gjentatte erfaringer av ikke å mestre fører til hjelpeløshet eller håpløshet og dette henger igjen sammen med utvikling av usunn livsstil. Sosialt miljø og utdannelse bidrar til å skille mellom dem som opplever å mestre og dem som ikke gjør det, hevder forfatterne.

Jon Ivar Elstad diskuterer en annen mulig forklaringsmekanisme for sammenhengen mellom sosial rang og helse: nemlig helserelatert seleksjon til ulike sosiale grupper. Denne teorien postulerer at i alle fall en del av ulikhetene skyldes at personer med dårlig helse tenderer til å gli nedover på den sosiale rangskala, mens personer med god helse tenderer til å bevege seg oppover i hierarkiet. Tidligere forskning tyder ikke på at denne sosiale seleksjonen spiller noen stor rolle for det totale ulikhetsmønsteret i Norge. Men Elstad diskuterer de sosialpolitiske implikasjoner av slike seleksjonsmekanismer, som - i den grad de finner sted - er urettferdige, men forhåpentligvis unngåelige.

I en studie av dødeligheten blant yngre kvinner og menn bosatt i Oslo, har Claussen og Nass etterprøvet seleksjonshypotesen. For menn som hadde uforandret status mellom 1960 og 1980 fulgte dødeligheten i perioden 1990-94 sosial klasse som forventet. Menn som beveget seg oppover yrkeskalaen over 20-års perioden, hadde lavere dødelighet og de som beveget seg nedover skalaen hadde høyere dødelighet sammenliknet med dem som hadde uendret status. For kvinner var bildet noe mer uklart, men i hovedsak likt det man fant hos menn. Dette gir empirisk støtte for at helserelaterte seleksjonsmekanismer faktisk forklarer en del av de observerte sosiale forskjeller i dødelighet.

En fjerde forklaringsmodell til sosiale ulikheter i helse, er knyttet til helsetjenesteforbruk. Personer i høyere sosiale lag kan ha bedre tilgang til helsetjenester. Slike eventuelle forskjeller i tilbud er også urettferdige og i strid med medisinsk etikk (15). Grøholt og Nordhagen bruker data fra en større nordisk undersøkelse av barn for å lete etter ulikheter i helse og helsetjenesteforbruk etter foreldrenes utdannelse. De fant høyere bruk av spesialisthelsetjeneste blant barn av foreldre med høyere utdannelse. Derimot var bruk av allmennpraktiker ikke relatert til foreldrenes utdannelse.

Temanummeret inneholder også to empiriske artikler om sosiale helsedeterminanter som ikke primært går på sosial klasse, men hvor sosial ulikhet kan tenkes å forklare noen av de observerte funn. Palner og Mittelmark brukte data fra den norske helseundersøkelsen 1995 for å se på sammenhengen mellom opplevd fysisk og psykisk helse hos henholdsvis gifte og ikkegifte personer. Generelt var det en klar sammenheng mellom fysisk og psykisk helse og man fant også en sammenheng mellom dårligere selvvurdert helse og lavere inntekt. Gifte rapporterte gjennomgående om bedre helse enn ikke-gifte, selv når det ble statistisk kontrollert for inntekt. Tveito og medarbeidere sammenliknet i en studie blant ansatte i kraftindustrien "storforbrukere" av sykepenger (over 10 fraværsdager siste 6 måneder) med de øvrige $90 \%$, og fant at disse to gruppene skilte seg fra hverandre på en lang rekke sosiale, helserelaterte, arbeidsmessige og psykologiske karakteristika.

Temanummeret avsluttes med en refleksjon av Espen Dahl om hvor vi står i Norge når det gjelder dokumentasjon, forskningsaktivitet og politikk. Også dette bidraget ble først fremført under Gardermoenkonferansen, og bærer det nedslående budskap at Norge er meget tilbakeliggende både når det gjelder forskning omkring sosial ulikhet og helse, og dessuten at det norske politiske etablissementet ikke ser ut til å ville gjøre noe med de forskjeller som faktisk er påvist. Dette skyldes ifølge Dahl en grunnleggende forestilling om at problemet egentlig dreier seg om restfattigdom og utsatte grupper, som det gjelder å få med seg i velstandsutviklingen, mens det grunnleggende problemet om at det dreier seg om en gradient som går tvers gjennom hele befolkningen overses. Kanskje er det her den store utfordringen kommer til å ligge for fremtidens tiltak: skal ulikhetsproblemet angripes med generelle politiske virkemidler for utjevning av levekår, slik tradisjonen har vært under oppbygging av velferdsstaten (1), eller skal det satses på sosialkontorløsninger og såkalte målrettede tiltak? 
Svaret ligger ikke i denne artikkelsamlingen. Men i bunnen ligger det avgjørende spørsmålet: vil det fortsatt være politisk vilje til å følge opp WHOs deklarasjon fra Alma Ata i 1977 med parolen om Helse for alle, der utjevning av helseulikheter mellom land og befolkningsgrupper er den første og mest sentrale målsetting? (16). Om så er, vil denne artikkelsamlingen være et nyttig utgangspunkt.

Som gjesteredaktører for dette spesialnummeret vil vi takke alle bidragsytere. Vi vil også rette en spesiell takk til tidsskriftets hovedredaktør, Trond Peder Flaten, som har vært initiativtaker og pådriver for å få utgitt dette temanummeret om sosial ulikhet og helse. Under en konferanse på Jægtvolden med nederlandske Johan P. Mackenbach i juni 2000 ble det åpenbart at den sosiale ulikhetsdimensjonen ville få økende betydning for forskning innen norsk epidemiologi, og han mente at Norsk forening for epidemiologi gjennom sitt eget tidsskrift burde målbære dette signalet. Det argumentet kunne vi ikke stå for.

\section{LITTERATUR}

1. Westin S. Velferd og helse i folketrygdens århundre. Tidsskr Nor Laegeforen 1999; 119: 4507-13.

2. Kuhnle S. Velferdsstatens idégrunnlag i perspektiv. I: Hatland A, Kuhnle S, Romøren TI (red). Den norske velferdsstaten. Oslo: Ad Notam Gyldendal, 1994: 9-28.

3. Westin S. Sosial klasse - dimensjonen som forsvant. Tidsskr Nor Lageforen 1994; 114: 2821-3.

4. Olsen B. Helse og ulikhet - er vår uskyldstid over? Tidsskr Nor Lageforen 1998; 118 : 13.

5. Mackenbach JP, Kunst AE, Cavelaars AEJ, Groenhof F, Guerts JJM, and the Working Group on Socioeconomic Inequalities in Health. Socioeconomic inequalities in morbidity and mortality in Western Europe. Lancet 1997; 349: 1655-9.

6. Dahl E. Social inequalities in health: A review of the Norwegian evidence. Oslo: Fafo - Fagbevegelsens forskningsinstitutt, 2000.

7. Rognerud MA, Stensvold I (red). Oslohelsa. Utredning om helse, miljø og sosial ulikhet i bydelene. Oslo: Oslo kommune - Ullevål sykehus, 1998.

8. SSB. Sosiale indikatorer 1980-2001. Samfunnsspeilet 2001; 4: 51-97.

9. Krokstad S, Westin S. Folkehelse, ulikhet og fattigdom. Vedlegg til: Statens Helsetilsyn, Tilsynsmelding 2001.

10. Marmot M. From Black to Acheson: two decades of concern with inequalities in health. Int J Epidemiol 2001; 30: $1165-71$.

11. Lahelma E, Lundberg O, Manderbacka K, Roos E (red). Health inequalities in the Nordic countries from the 1980s to the 1990s. Scand J Public Health 2001, Suppl. 55.

12. Brekke M. Influence of social inequality and self-efficacy on rheumatoid arthritis and non-inflammatory musculosceletal pain. Oslo: Faculty of Medicine, University of Oslo, 2002.

13. Krokstad S, Kunst AE, Westin S. Trends in health inqualities by educational level in a Norwegian total population study. J Epidemiol Community Health 2002; 56: 375-80.

14. Kuh D, Ben-Shlomo Y. A life course approach to chronic disease epidemiology. New York: Oxford University Press, 1997.

15. Westin S. Likhet og brorskap verneverdige verdier i helsetjenesten. Tidsskr Nor Lageforen 1999; 119: 1474-9.

16. Helsedirektoratet. Helse for alle i Norge? Oslo: Helsedirektoratet/ Kommunalforlaget, 1987.

\section{Gjesteredaktører}

\section{John Gunnar Mæland}

Institutt for samfunnsmedisinske fag Universitetet i Bergen john.meland@isf.uib.no

\section{Steinar Westin}

Institutt for samfunnsmedisinske fag NTNU

steinar.westin@medisin.ntnu.no

\section{Kjell Haug}

Institutt for samfunnsmedisinske fag Universitetet i Bergen kjell.haug@isf.uib.no 